\title{
Phosphorus disequilibrium in the tripartite plant- ectomycorrhiza-plant growth promoting rhizobacterial association
}

\author{
J.R. Cumming ${ }^{1 *}$, C. Zawaski ${ }^{1}$, S. Desai ${ }^{2}$, F.R. Collart ${ }^{2}$ \\ ${ }^{1}$ Department of Biology, West Virginia University, Morgantown, WV, 26501 USA. ${ }^{2}$ Biosciences Department, \\ Argonne National Laboratory, Argonne, IL, 60439 USA. *Corresponding author:Jonathan.Cumming@mail. \\ wvu.edu
}

\begin{abstract}
Plant roots and rhizospheres are colonized by an extensive and diverse microbial community. These microbes may form mutualistic, commensal, and/or pathogenic relationships and influence agricultural and forest productivity. Symbiotic ectomycorrhizal (EcM) fungi colonize the roots of many tree species, and the literature on these associations extensively describes their influence on plant nutrient relations and response to environmental stress. Similarly, soil bacteria ubiquitously colonize roots and rhizospheres and many of these bacteria may also play roles in influencing tree productivity. In particular, plant growth promoting rhizobacteria (PGPR) positively affect plant growth by altering nutrient availability in soils and inducing changes in plant hormone balance, plant stress resistance, and immunity pathways. In nature, EcM fungi and soil PGPR co-exist and the interaction and composition of this multi-tiered rhizosphere community aids in the acquisition of nutrient resources from soils as well as host plant response to environmental stress. The assembly of EcM communities is influenced by tree species and environmental conditions, and the tree and EcM species further influence PGPR community structure. Functionally, these symbiotic associations exhibit unique expression profiles and ecophysiological activities within the tripartite association. EcM and PGPR mediate production of complex arrays of exudates, including organic acids, siderophores, enzymes, and other organic compounds, which alter nutrient equilibria in soils, leading to increased access to phosphorus $(\mathrm{P})$ and other macro- and micronutrients. As a metaorganism, the tripartite ectomycorrhizas increase the ecological breadth of host trees and influence the structure and function of forested ecosystems.
\end{abstract}

Keywords: Ectomycorrhizal fungi, mineral weathering, mycorrhizal helper bacteria, nutrient scavenging, phosphate

\section{Introduction}

Microbes in the rhizosphere play a significant role in the relationship of trees to soils and environmental stresses. Soil microbes are numerous and diverse, and play roles that are pathogenic, commensal, and symbiotic in nature (Barton and Northup, 2011). They increase the ecological breadth of trees, i.e., broaden the conditions under which many tree species can function (Adriaensen et al., 2005; 
Augé, 2004; Seguel et al., 2013). Together with the terrestrial vegetative community, the root-associated microbial community influences and mediates the biogeochemical cycling of nutrients, such as NP and sulfur (S), and thus is critical in forest productivity and the provision of ecosystem services (Barton and Northup, 2011; Berg and Smalla, 2009; Chapman et al., 2006).

The roots of the vast majority of forest tree species form mycorrhizal associations (Smith and Read, 2008) with species in boreal, temperate, and tropical forests forming relationships with ectomycorrhizal $(\mathrm{EcM})$ fungi. In exchange for $\mathrm{C}$ in the form of sugars, $\mathrm{ECM}$ fungi integrate the host tree into soil nutrient cycles and provide physical, physiological, and biochemical access to nutrients in the soil that the host tree would otherwise be unable to access (Buée et al., 2007; Phillips and Fahey, 2006; Zhao and Running, 2010). For example, both $\mathrm{N}$ and $\mathrm{P}$ are limited in forests due to high biological demand in soils and/or recalcitrance of mineral and organic forms of these critical nutrients that lead to their inherent limitation to forest tree roots. EcM fungi possess metabolic pathways that allow access to these nutrients and, thus, provide access to their hosts as well (Buée et al., 2007; Chalot and Brun, 1998; Phillips and Fahey, 2006; Plassard and Dell, 2010; Zhao and Running, 2010). This ecological access to nutrients extends beyond the influence of the rhizosphere itself into the region of influence of mycorrhizas in the soil- the mycorrhizosphere.

In addition to accessing nutrients from recalcitrant soil pools, EcM fungi and the mycorrhizosphere provide a unique niche in which soil microbes, including a vast community of bacteria, reside and these may also contribute metabolic and ecological enhancement of nutrient acquisition (Frey-Klett et al., 2007). Here, these plant growth promoting rhizobacteria (PGPR), or mycorrhizal helper bacteria (MHB), receive benefits from the host mycorrhiza, including $\mathrm{C}$ and a physical niche, and may provide numerous direct and indirect benefits to host trees and influence their associated EcM fungi. Benefits of PGPR to the host include stimulation of root growth, nutrient acquisition, and modification of rhizosphere microbial communities (Cassán et al., 2014; FreyKlett et al., 2007; Hrynkiewicz et al., 2010; PerselloCartieaux et al., 2003; Rogers et al., 2012), all of which improve tree performance and resistance to environmental stress.

For the purpose of this review, we are focusing on the tripartite relationships of the roots of tree species with symbiotic EcM fungi and plant growth promoting rhizobacteria. In addition, we are focusing further on the role of the tripartite association in the acquisition of limiting resources, notably $\mathrm{P}$, from the soil ecosphere.

\section{Building Community - the Formation of Mycorrhizosphere Associations}

Plant-mycorrhizal associations have existed since the colonization of land by autotrophic plant ancestors (Graham and Miller, 2005). Since these first arbuscular-like mycorrhizal relationships, selection and specialization have led to numerous and diverse mycorrhizal associations, some more narrow and some more cosmopolitan in nature. These include the arbuscular mycorrhizas, ericoid mycorrhizas, arbutoid mycorrhizas, monotropoid mycorrhizas, orchid mycorrhizas, and ectomycorrhizas, the focus of this review.

Ectomycorrhizas typically form between roots of woody plants and fungibelonging to the Basidiomycota, Ascomycota, and Zygomycota (Tedersoo et al., 2010). The ecological and physiological benefits of the EcM fungal association are well studied (Smith and Read, 2008), and include improvements in host nutrient and water acquisition as well as enhanced stress resistance 
(Cairney, 2012; Chalot and Brun, 1998; Courty et al., 2010; Plassard and Dell, 2010; van Hees et al., 2006).

These associations vary in host-fungus specificity: the associations may be narrow, perhaps reflecting specialization to specific ecological conditions or strategies to limit competition (den Bakker et al., 2004; Molina et al., 1992) or may be broad, reflecting greater flexibility of fungi to occupy broad soil ecological niches (Rosling et al., 2003).

Also present in the rhizospheres of trees are a wide variety of bacteria (Brown et al., 2012; Calvaruso et al., 2007; Frey-Klett et al., 2007), which, when providing growth benefit to the host, are termed plant growth promoting rhizobacteria (PGPR) (Compant et al., 2010; Khan et al., 2009; Persello-Cartieaux et al., 2003; Rodríguez and Fraga, 1999). As with mycorrhizal symbiosis, the plant-PGPR relationship is probably ancient and based on the availability of carbon (C) from the autotrophic host root that may be exchanged for benefit to the host plant. These benefits include access to nutrients, biological control in the rhizosphere, and alteration of phytohormone levels, which increase host vigor, stress resistance, and broaden the ecological niche of the host (Babalola, 2010; Barriuso et al., 2008; Bent et al., 2001; Compant et al., 2010; Persello-Cartieaux et al., 2003).

\subsection{EcM Community Selection}

Generalist ECM fungi, such as Amanita muscaria, may be found in association with many host genera across widely different environments. Such generalization would promote extensive EcM species radiation and may reflect adaptability of the EcM fungus (Cairney, 2000; Courty et al., 2010; Taylor et al., 2006). In contrast, specialization may reflect historical bottlenecks, such as in glacial refugia, or ecological specialization that constrained the number of host-symbiont combinations (Brundrett, 2009;
Courty et al., 2010; den Bakker et al., 2004). As hostsymbiont specialization is retained, there must exist unique host-fungal combinations that function to provide optimum benefit within the ecological range of the symbiont pair.

Although the controls over host-EcM fungal specificity are not yet described, patterns of specificity suggest that the plant host influences, to some extent, the ecology of the mycorrhizosphere. Culture studies have noted distinct host-EcM specificities. Massicotte et al. (1994) noted strong mycorrhization preferences among six tree species and $15 \mathrm{EcM}$ fungal species, with none of the fungi having broad host ranges. However, a study of host-EcM fungal specificity among five tree species grown in soil indicated that specificity is significantly less strict, but still present (Massicotte et al., 1999). Further, host-EcM specificity was low among five tropical tree species and $39 \mathrm{EcM}$ fungi collected from field soils in New Guinea (Diedhiou et al., 2010). Interestingly, in this study, specificity varied by host-species life stage, with seedlings tending to support a more diverse EcM community, a pattern supported for Populus balsamifera along a glacial chronosequence (Helm et al., 1996), but not for Pinus thunbergii in a forest with low EcM fungal species diversity to begin with (Obase et al., 2009). Thus, it is difficult to make generalizations regarding the development of EcM fungal communities. Community structure varies with host species as well as the age or stage of the host, depends on the surrounding edaphic conditions, and may be restricted by the diversity of propagules from the surrounding ecosystem (Elliott et al., 2007)

\subsection{PGPR Community Selection}

The structuring of bacterial communities by plant hosts may also favor plant performance under specific environmental conditions. Evidence indicates that specific plant host-bacterial combinations may 
be encouraged, perhaps as a result of the "biased rhizosphere effect" (Hartmann, et al. 2009). According to this hypothesis, host exudation profiles enrich the root zone in specific bacterial groups due to the presence of both stimulatory and inhibitory factors (Babalola, 2010; Hartmann et al., 2009). This selection may, in turn, alter root function/exudation and further bias the maintenance of a limited number of bacterial groups in the plant rhizosphere (Hartmann et al., 2009). In the field, the majority of forest tree roots will be colonized by symbiotic EcM. As this is the norm, an investigation of host tree-bacterial community selection will be nearly impossible to separate from selection mediated by the resident EcM fungal community. Several reports indicate that specific EcM fungal species influence the composition of the microbial community formed in the mycorrhizosphere. Roots of Betula pubescens, for example, form mycorrhizas with numerous EcM species and these species differentially influence bacterial and ascomycete communities (Izumi and Finlay, 2011). Across the EcM associates, both cosmopolitan and EcMspecies specific bacterial profiles were found (Figure 1), with additional selection existing for ascomycetes (Izumi and Finlay, 2011). Similar bacterial community selection has been reported between Lactarius vellereus and Lactarius subdulcis mycorrhizas of Fagus sylvatica (Mogge et al., 2000) and noted for Rhizopogon sp. (Kretzer et al., 2009).

Interestingly, endophytic bacterial communities of mature Populus deltoides trees from upland and bottomland soils in Tennessee, USA were dramatically different from rhizosphere samples, suggesting that a further level of selection and potential host specificity leads to a narrow community of bacterial living within the root proper (Gottel et al., 2011). Elucidation of the functional attributes of endophytic communities vis-à-vis rhizospheric communities remains a potentially fruitful area of research.

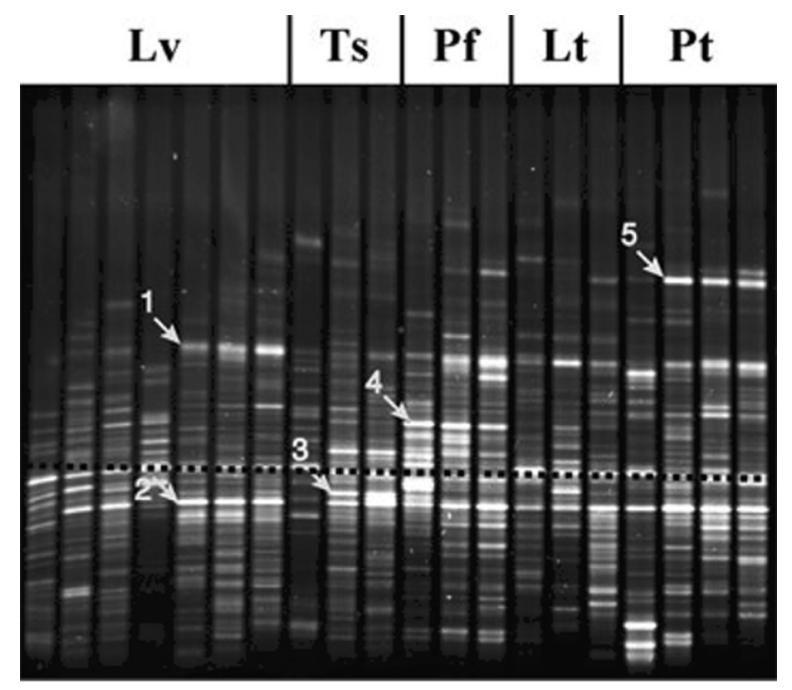

Figure 1. DGGE profile of the bacterial communities associated with the mycorrhizas of Betula pubescens. EcM mycorrhizas: Lv =Leccinum variicolor $; \mathrm{Ts}=$ Tomentellopsis submollis; $\mathrm{Pf}=$ Piloderma fallax $; \mathrm{Lt}=$ Lactarius torminosus $; \mathrm{Pt}=P$ seudotomentella tristis. Bacterial associate sequence homology: 1 =Acidobacteriaceae; $2=$ Rhodopseudomonas palustris; $3=$ Rhizobium leguminosarum; 4 = Mesorhizobium sp.; 5 = Mucilaginibacter sp. Note the cosmopolitan associates (bands 1, 2) and EcMspecific associates (bands 3, 5). Reproduced from Izumi and Finlay (2011) with permission. 


\subsection{PGPR-EcM Community Interactions}

That the EcM fungi and PGPR communally occupy the same physical space raises questions regarding co-selection and mutualistic or antagonistic relationships between the two groups and subsequent functional implications for the host tree. Indeed, several reports suggest that there may be complex interactions that ultimately influence structural and functional aspects of the mycorrhizospheric community, and thus will influence the ecological breadth of the plant-EcMbacterial tripartite association.

In addition to the influence of EcM fungal species on PGPR communities noted above, mycorrhizospheric bacterial isolates have been found to alter relationships between $\mathrm{EcM}$ and host tree roots. Streptococcus sp. stimulated both mycelial growth in vitro and colonization of roots of Picea abies by A. muscaria (Riedlinger et al., 2006). Garbaye and Bowen (1989; 1987) found that bacterial isolates from the mycorrhizospheres of Pinus radiata differentially influenced mycorrhization by Hebeloma crustuliniforme, Paxillus involutus, and Rhizopogon luteolus. Similar influences were noted for Pseudomonas fluorescens and the Acacia holosericea-Pisolithus sp. symbiosis (Founoune et al., 2002) and for Sphignomonas paucimobilis and Ralstonia pickettii in symbiosis with Salix viminalis (Hrynkiewicz et al., 2010). In an uncontrolled soil experiment, inoculation of Pinus pinea seedlings with Arthrobacter sp., but not Staphylococcus spp., stimulated EcM root tip production and, further, each PGPR fostered a different EcM fungus to dominate the root system (Barriuso et al., 2008). These community structural controls over EcM populations will have functional implications for the tree host.

\subsection{Communication in the Tripartite Community}

Accessing soil resources is the central role of the complex root-symbiont community. An effective balance between supply and demand of nutrients and the deployment of $\mathrm{C}$ into the rhizosphere will require communication between partners and the integrated expression of their genomes. These interactions between mycorrhizosphere members may result from the production of diffusible compounds that may trigger metabolic and growth responses in symbiosis. Actinomycetes produce compounds that regulate the growth of soil-borne fungi and these exudates may function to structure the microbial communities of tree roots (Riedlinger, et al. 2006, Keller, et al. 2006). The PGPR Streptomyces strain AcH 505, for example, produces several compounds that regulate fungal activity (Keller, et al. 2006). One such exudate, auxofuran, is a compound with structural similarity to auxin and it stimulates the growth of A. muscaria in vitro (Riedlinger, et al. 2006, Keller, et al. 2006) and the formation of mycorrhizas in symbio (Schrey et al., 2005). Auxofuran was also found to induce changes in gene expression in A. muscaria, with up-regulation of a number of metabolism-related genes such as acetoacetyl-CoA synthetase to support ergosterol production (Schrey et al., 2005). Genes related to cell-cell interactions, stress response, and metabolism were differentially expressed in Laccaria bicolor when challenged with beneficial, neutral, or antagonistic bacteria (Deveau et al., 2014), with the PGPR P. fluorescens BBc6R8 inducing greater expression of transcription factors and transcripts related to chromatin structure and stress response. A large number of $P$. fluorescens isolates altered gene expression in L. bicolor and increased root colonization of three Populus species (Labbe et al., 2014), again supporting the complex relationships 
underlying microbial community structure in the mycorrhizosphere.

While little information on EcM fungi-PGPR crosstalk is available for tree species, there is evidence that coordinated messages are exchanged that reflect nutrient demands of the plant hosts. Root exudates from nutrient stressed maize plants altered gene expression in Bacillus amyloliquefaciens in vitro, with the greatest changes under $\mathrm{N}$ limitation (Carvalhais et al 2013). These conditions induced stress response genes in B. amyloliquefaciens, which may reflect a selection pressure on the PGPR community by the host (Carvalhais et al., 2013). Exudates from P, iron (Fe), and potassium $(\mathrm{K})$ deficient plants had much lesser effects on gene expression in B. amyloliquefaciens in exponential growth phase and, by and large, induced up-regulation of chemotaxis-, motility-, and transportrelated genes, again suggesting that, under these nutrient conditions, the host may provide signals that select PGPR community assemblages. In support of this, Zyśko et al. (2012) noted that gene expression in Pseudomonas aeruginosa growing the rhizosphere of Lolium perenne was broadly altered by P limitation, which may have reflected alterations in root exudation in response to $\mathrm{P}$ starvation. Conversely, colonization of Arabidopsis thaliana by Bacillus subtilis activated the $\mathrm{Fe}$ acquisition machinery to increase Fe uptake in through elevated transcription factors that stimulated ferric reductase and an iron transporter (Zhang et al., 2009).

Clearly, complex signals and responses between mycorrhizosphere microbes and perhaps the plant host function to establish the structure and function of the community of the tripartite symbiosis. As the acquisition of nutrient resources is perhaps the keystone attribute of root symbiotic associations, the role of the tripartite symbiosis in the biological cycling of recalcitrant and limiting nutrients such as $\mathrm{P}$ is critical to forest ecosystem productivity.

\section{Changes in Phosphorus Disequilibrium by Structured Mycorrhizosphere Communities}

Soil nutrient limitation, especially $\mathrm{N}$ and $\mathrm{P}$, limits the productivity of many natural and planted forests (Hou et al., 2012; St. Clair et al., 2008; Wardle et al., 2004). To overcome $\mathrm{P}$ limitation, trees rely on integrated physiological acclimation systems that increase phosphate $\left(\mathrm{P}_{\mathrm{i}}\right)$ availability in the rhizosphere and $\mathrm{P}_{\mathrm{i}}$ uptake (Plaxton and Tran, 2011). Additionally, trees depend on the activity of symbiotic mycorrhizal fungi and PGPR to meet their nutritional demands (Calvaruso et al., 2006; Plassard and Dell, 2010; Yang et al., 2009). Symbiont stimulation of nutrient acquisition by forest trees is fostered by changes in root surface area and $\mathrm{Pi}$ acquisition affinity, increased soil exploration by EcM hyphae, and changes in exudation profiles of enzymes and small molecular weight compounds produced by both EcM fungi and PGPR.

\subsection{Modulation of $P_{i}$ Transporter Affinity by EcM Fungi}

Stimulation of P uptake by EcM fungi will lead to increased dissolution of $\mathrm{P}_{\mathrm{i}}$ complexes by altering equilibria concentrations in the soil solution. Increases in the affinity of $\mathrm{P}_{\mathrm{i}}$ uptake will be more effective than increasing $\mathrm{P}_{\mathrm{i}}$ uptake capacity (Machado and Furlani, 2004). Increased $P_{i}$ acquisition by roots of Populus tremuloides colonized by L. bicolor resulted from higher affinity for $\mathrm{P}_{\mathrm{i}}$ uptake by mycorrhizal roots $\left(k_{m}=6.5 \mu \mathrm{M}\right)$ than NM roots $\left(k_{m}=36.9 \mu \mathrm{M}\right)$ (Desai et al., 2014). Similarly, the EcM fungi $P$. involutus, Thelophora terrestris, and Suillus bovinus increased $\mathrm{P}_{\mathrm{i}}$ uptake due to the higher affinity of EcM roots in Pinus sylvestris (Van Tichelen and Colpaert, 2000). These changes in $\mathrm{P}_{\mathrm{i}}$ uptake affinity may reflect changes in $\mathrm{P}_{\mathrm{i}}$ transporter expression in the host plant 
resulting from symbiosis and/or the operation of EcM transporters with innately greater affinity for $\mathrm{P}_{\mathrm{i}}$ in the mycorrhizosphere (Becquer et al., 2014; Loth-Pereda et al., 2011; Plassard and Dell, 2010). In Populus trichocarpa, for example, the expression of several $\mathrm{P}_{\mathrm{i}}$-transporter genes was differentially regulated by EcM (as well as AM symbionts) (Loth-Pereda et al., 2011), reflecting the role of mycorrhizal community diversity in influencing $\mathrm{P}_{\mathrm{i}}$ acquisition potential of the host under P limitation. Such increases in the affinity for $\mathrm{P}_{\mathrm{i}}$ uptake induced by EcM fungal colonization will alter chemical equilibria in the mycorrhizosphere and maintain the flow of $\mathrm{P}_{\mathrm{i}}$ to the host plant.

\subsection{Changes in Exudation Mediated by EcM Fungi}

Working in concert with changes in uptake kinetics, the association of EcM with the short roots of trees has been shown to alter chemical equilibria of $\mathrm{P}_{\mathrm{i}}{ }^{-}$ containing minerals in the soil. Such changes in mineral solubility may result from changes in the deposition of a variety of C-containing compounds capable of chelating metals such as aluminum $(\mathrm{Al}), \mathrm{Fe}$, and calcium $(\mathrm{Ca})$, which often control $\mathrm{P}_{\mathrm{i}}$ solubility. Mineral weathering may reflect enhanced production by the host root and/or EcM fungus of common exudates, such as low molecular weight organic acids (LMWOAs), or the production of novel compounds by EcM, including siderophores such as ferricrocin, that aid in dissolution reactions in the mycorrhizosphere (Baldwin, 2005; Becquer et al., 2014; Hrynkiewicz et al, 2010; Johannsson et al., 2009; Plassard and Dell, 2010).

Several studies reporting exudation rates for LMWOAs suggest that colonization of tree roots by EcM fungi either reduces or does not affect the production of organic acids, including malate, citrate, and oxalate, which would alter $\mathrm{P}_{\mathrm{i}}$-containing compound dissolution in the mycorrhizosphere. In
P. tremuloides, colonization of roots by L. bicolor reduced the exudation of LMWOAs at any specific $\mathrm{P}_{\mathrm{i}}$ concentration in the rhizosphere, an effect due to the change in response thresholds resulting from enhanced $\mathrm{P}_{\mathrm{i}}$ uptake (Desai et al., 2014). Oxalate production by Pinus pinaster mycorrhizas were symbiont dependent, with those formed with Rhizopogon roseolus, but not Hebeloma cylindrosporum, excreting oxalate (Casarin et al., 2003). Similarly, Johansson et al. (2008, 2009) noted limited differences in LMWOA exudation in P. sylvestris colonized by several EcM symbionts. However, roots of $P$. sylvestris colonized by six EcM species produced 6.7- to 13.6-fold greater dissolved organic C (DOC) in comparison with nonmycorrhizal roots (Johansson et al., 2008), suggesting that novel C-containing compounds produced by roots colonized by EcM fungi may play important roles in mycorrhizospheric processes. In contrast, exudation by roots of $P$. sylvestris colonized by $H$. longicaudum, P. involutus, or Piloderma croceum exhibited generally similar overall exudation, although the profile of LMWOAs varied between EcM and nonmycorrhizal roots (Van Schöll et al., 2006). Colonization of roots of P. tremuloides by L. bicolor similarly altered organic acid profiles in the mycorrhizosphere, but, in contrast to Johansson et al. (2008), reduced the flux of DOC to the rhizosphere, especially when $\mathrm{P}_{\mathrm{i}}$ in the environment was limiting (Desai et al., 2014). Such differences may reflect differences between hosts and/ or symbionts in physiological processing of $\mathrm{C}$.

Several novel compounds produced by EcM fungi may alter chemical equilibria in the rhizosphere. Hydroxymate siderophores, for example, play roles in the Fe nutrition of plants through their capacity to chelate and solubilize sparingly soluble Fe-containing minerals (Marschner and Marschner, 2012). At the same time, the production of such metal-chelating molecules may also alter $\mathrm{P}_{\mathrm{i}}$ availability. Isolates of $P$. involutus differed in their production of siderophores, 
with an isolate with greater production stimulating the growth of $S$. viminalis to a greater extent (Hrynkiewicz et al., 2010). In P. sylvestris mycorrhizas, for example, H. crustuliniforme hyphae produced ferricrocin (Van Hees et al., 2006). Exudates from Pisolithus tinctorius with high affinity for AL were collected by metal ion affinity chromatography and compounds ranging between 400 and $2000 \mathrm{Da}$ were identified as compounds active in metal binding (Baldwin, 2005). That these masses are large compared to LMWOAs (citrate $=191$, for example), there appears to be a collection of large exudate molecules yet to be described with the potential to mediate nutrient dissolution reactions.

\subsection{Changes in $P_{o}$ Scavenging Enzymes Mediated by EcM Fungi}

In addition to stimulating the production of metalchelating compounds by host roots or producing novel EcM fungal-derived weathering agents, the EcM symbiosis may alter the cycling of $\mathrm{P}$ in the mycorrhizosphere through the production of organic $\mathrm{P}$ $\left(\mathrm{P}_{\mathrm{o}}\right)$-scavenging enzymes, such as acid phosphatases (APases) and phytases (Courty et al., 2010). These enzymes have the capacity to split phosphate ester bonds in organic complexes, freeing up $\mathrm{P}_{\mathrm{i}}$ for subsequent uptake. As the forest soil $\mathrm{P}$ pool may be dominated by $\mathrm{P}_{\mathrm{o}}$ (Ali et al., 2009; Criquet et al., 2004) that is otherwise not available to plants, access via EcM fungi associated with tree roots would greatly enhance the P nutrition of the host.

EcM fungi exhibit a wide range of capacities to access $\mathrm{P}_{\mathrm{o}}$. Numerous in vitro studies suggest that EcM may access a broad range of P-monoesters, such as sugar phosphates, nucleotide phosphates, and polyphosphates, as well as phytic acid (Louche et al., 2010; Nygren and Rosling, 2009). In soils, Ali et al. (2009) found that mycorrhizas of $P$. pinaster exhibited a range of APase activities and were responsive to environmental $\mathrm{P}$ limitation, increasing as soil extractable $\mathrm{P}_{\mathrm{i}}$ declined. Similarly, APase rates varied widely between Nothofagus oblique mycorrhizal with P. tinctorius, P. involutus, Cenococcum geophilum, and Descolea antartica (Alvarez et al., 2012). Interestingly, Courty et al. (2011) found that phosphatase rates of 40 genotypes of Populus varied extensively, and, while rates were greatly increased by the association of L. bicolor with roots, patterns of variation among host genotypes did not change, which suggests that APase activity is under control of the host tree, yet stimulated by the EcM symbiont.

\subsection{Modulation of $P_{i}$ Transporter Affinity by PGPR}

The association of PGPR with the roots of many plant species often stimulates growth and nutrient acquisition due to changes in a variety of both environmental and plant factors (Bhattacharyya and Jha, 2012; Compant et al., 2010; PerselloCartieaux et al., 2003; Yang et al., 2009). Among these may be changes in host root ion transporter behavior that would favorably benefit nutrient acquisition. As $\mathrm{P}_{\mathrm{i}}$ is available sparingly in most soils, especially those not managed by fertilization, changes in $\mathrm{P}_{\mathrm{i}}$ transport affinity or capacity would benefit plant $\mathrm{P}_{\mathrm{i}}$ acquisition from the rhizosphere. Unlike EcM fungi, however, PGPR do not form a fungal mantle that serves as in interface between the soil solution and root cortical cells. It is this fungal sheath that may mediate changes in ion transport noted above-indeed it may be difficult, at the flux level, to disentangle EcM from host uptake systems in the mycorrhiza. For PGPR, however, changes in root ion uptake would have to result from changes in host physiology modulated by a signal from the bacteria.

PGPR provide significant benefits to their hosts in P-limiting environments. In Populus tremuloides, for 
example, inoculation with $P$. fluorescens significantly improves plant performance at low $\mathrm{P}_{\mathrm{i}}$ in vitro (Figure 2). Such benefits may result from alterations in $P_{i}$ transporter expression in the host root, such as those noted for mycorrhizal fungi, above. Given the growth and nutrient-stimulating effects of PGPR on many plant species, it is surprising that data on ion uptake/flux is limited (Mantelin and Touraine, 2004). At the same time, linkages between developmental growth changes induced by PGPR and nutrient demand confound assessment of potential direct mediation of plant transport system activity by PGPR (Mantelin and Touraine, 2004). In one of few studies in (Mantelin and Touraine, 2004). In one of few studies in this area, Bertrand et al. (2000) noted that inoculation of roots of Brassica napus by Achromobacter stimulated $\mathrm{NO}_{3}^{-}$and $\mathrm{K}^{+}$uptake rates while increasing $\mathrm{H}^{+}$extrusion. These findings suggest that there was an increase in energization of cortical cells by the PGPR that may have stimulated the driving forces for ion transport (Bashan, 1990). Given the extensive data showing PGPR stimulation of plant growth and nutrient efficiency, there seems to be ample room for research on the nutrient transport mechanisms underlying these benefits.

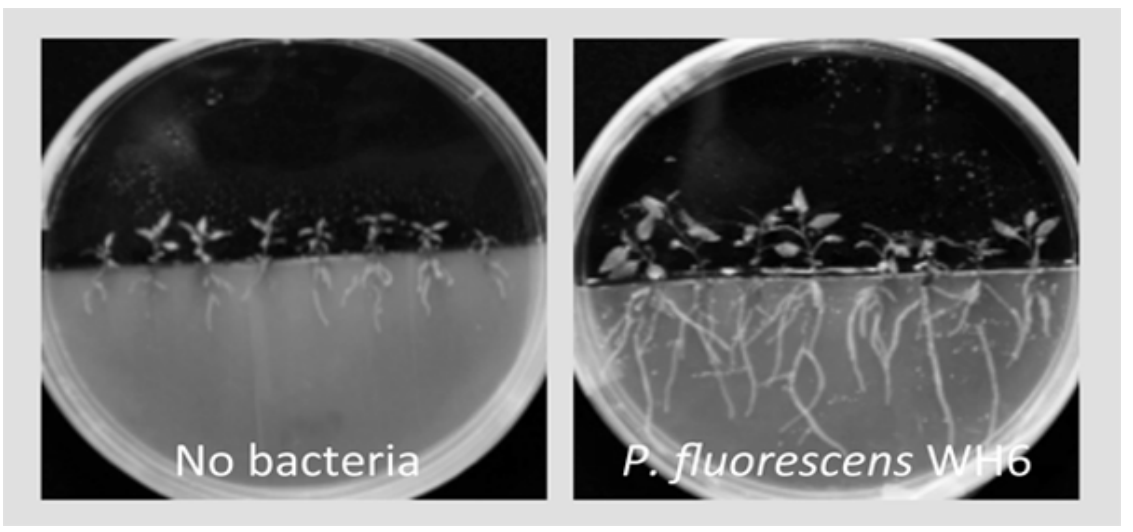

Figure 2. Growth of Populus tremuloides on nutrient agar containing $25 \mu \mathrm{M}$ Pi. Plants were not inoculated (left) or inoculated with Pseudomonas fluorescens strain WH6 (right) (Desai and Collart, unpublished).

\subsection{Changes in Exudation Mediated by PGPR}

PGPR play a significant role in producing a suite of compounds that weather minerals in the rhizosphere (Bhattacharyya and Jha, 2012; Cassán et al., 2014; Compant et al., 2010; Persello-Cartieaux et al., 2003; Yang et al., 2009), which establishes their functional role as "phosphate solubilizing bacteria" (Khan et al., 2009; Rodriguez and Fraga, 1999). Additionally, PGPR may stimulate exudation of compounds by their host plants capable of altering nutrient disequilibria, which could also play a role in altering nutrient solubility equilibria in the rhizosphere. However, research in this area is scarce. In one of the few reports assessing the influence of PGPR on host root exudation patterns, Liu et al. (2013) found that Fraxinus americana, inoculated with B. subtilis, exhibited significant increases in the root exudation of sugars, amino acids, and organic acids. These changes suggest that the PGPR may influence nutrient/energy 
resource flow from the plant to the rhizosphere, which could also alter P-containing mineral solubility.

\subsection{Changes in $P_{o}$ Scavenging Enzymes Mediated by $P G P R$}

Many of the benefits of PGPR are derived from increased cycling of $\mathrm{P}$ in the plant rhizosphere, and most data related to the P benefit of PGPR has focused on the dissolution of sparingly soluble inorganic P complexes. However, access to soil $\mathrm{P}_{\mathrm{o}}$ reserves would also benefit host nutrition, especially in forest soils where $\mathrm{P}_{\mathrm{o}}$ is prevalent. A variety of PGPR exhibit both APase and phytase activities (Franco-Correa et al., 2010; Idriss et al., 2002; Turan et al., 2012) and, in some cases, this translates to improved plant performance. In relation to forest tree species, Li et al. (2013) isolated 17 phytate-degrading bacterial strains from Populus euramericana and Pinus massoniana plantation soils. As with EcM fungi, phytic acid degradation activity varied extensively among isolates.

\section{Phosphorus Disequilibrium in Complex Mycorrhizosphere Communities}

Microbe-mediated changes in root system/ mycorrhiza $\mathrm{P}_{\mathrm{i}}$ uptake affinities and rates as well as in $\mathrm{C}$ flux to the mycorrhizosphere will alter mineral weathering in the soil (Finlay et al., 2009; Finlay, 2008). Reactions driven by acidification and ligand binding will foster $\mathrm{P}_{\mathrm{i}}$ (and organic P-containing compound) release from minerals and complexes in the mycorrhizosphere. Release of phosphatases and phytases would foster the cycling of organic-P molecules. Both processes would increase $P_{i}$ availability to the tripartite association and the plant host.

\subsection{Increasing Mineral $P_{i}$ Dissolution}

EcM fungi colonize the vast proportion of root absorptive surfaces of forest trees and fungi integrate their host plants into biogeochemical cycles by facilitating the weathering of soil minerals (Blum et al., 2002; Finlay et al., 2009). Although the role of each EcM species in a soil may vary, many increase $\mathrm{H}^{+}$extrusion, organic acid and DOC exudation, and weathering of soil minerals.

At a scale focusing on biogeochemical evidence, isotopic signatures indicated that apatite was a significant source of $\mathrm{Ca}$ (and hence $\mathrm{P}$ ) in forests dominated by spruce and fir, but not by sugar maple (Blum et al., 2002). Similarly, soil analyses from the mycorrhizospheres of Abies lasiocarpa indicated that Piloderma sp. facilitated significant changes in cation availability (Arocena and Glowa, 2000) and microscopic evaluation of soil minerals associated with EcM hyphae indicted biofilms, structural modifications, and dissolution patterns indicative of biological weathering (Augusto et al., 2000; Saccone et al., 2012; van Breemen et al., 2000). In a root exclusion study, rock phosphate dissolution in a hyphal compartment in a field soil was correlated with soil acidification mediated by fungal hyphae of Pinus radiata (Liu et al., 2005).

Experiments at the plant level, where environmental conditions are more controlled, support field observations that the capacity of EcM fungi in mineral weathering varies by species. For example, Wallander (2000) noted significant weathering of apatite mediated by Suillus variegatus on P. sylvestris, and this dissolution was related to oxalate concentrations in the root zone. Nonmycorrhizal seedlings also facilitated apatite dissolution, but to a lesser extent. Similarly, $R$. roseolus, which facilitated oxalate exudation in $P$. pinaster, accessed hydroxyapatite in soils (Casarin et al., 2004). The dissolution of 
berlinite by Pinus rigida colonized by $P$. tinctorius was mediated by unidentified exudates, however nonmycorrhizal plants were unable to breakdown this compound (Cumming and Weinstein, 1990). Dissolution of iron ore varied among $P$. tinctorius, $P$. involutus, L. bicolor, and Suillus tomentosus on Pinus patula, which produced fungal-specific exudation profiles (Adeleke et al., 2012).

One of the best-noted roles of PGPR in promoting plant growth is their ability to solubilize $\mathrm{P}$ from a variety of P-containing minerals (Gyaneshwar et al., 2002; Khan et al., 2009; Rodriguez et al., 2006). There is a vast literature supporting siderophoremediated mineral dissolution (Leong, 1986; Loper and Henkels, 1999; Rodríguez and Fraga, 1999). In soils, certain Burkholderia glathei isolates facilitated the dissolution of biotite in the rhizosphere of $P$. sylvestris, and increased acquisition of $\mathrm{K}^{+}$and $\mathrm{Mg}^{2+}$ for the plant (Calvaruso et al., 2006). Such benefits may be direct, i.e., bacteria produce new compounds that are functionally more active in the weathering process, or indirect, i.e., the bacteria stimulate plant root growth and increase their capacity to weather minerals (Calvaruso et al., 2006). Similarly, PGPR were capable of promoting the growth of several cactus species through the production of organic acids that acidify the substrate and increase the dissolution of rhyodacite other substrates (Lopez et al., 2012; Puente et al., 2004).

To support chemical weathering of substrates, several in vitro studies have investigated the production of $\mathrm{H}^{+}$and organic acids by PGPR and their impacts on mineral dissolution. Chen et al. (2006) assayed 36 environmental strains selected for P-solubilizing capacity and noted that dissolution of tricalcium phosphate was associated with culture acidification. Further, isolates produced unique profiles of citric acid, gluconic acid, lactic acid, succinic acid, and propionic acid (as well as three unknowns), although there was no clear pattern suggesting any particular acid was more effective than others (Chen et al., 2006). In 45 Collimonas strains, tricalcium orthophosphate and biotite solubilization was associated with acidification of the media, although these strains also produced gluconic acid that may serve as a weathering agent (Uroz et al., 2009). Interestingly, of two effective phosphate-solubilizing bacteria, only Enterobacter aerogenes conferred a growth benefit to host Phaseolus vulgaris plants grown with tricalcium phosphate, suggesting that in vitro screening may not reflect performance in symbio or that host-PGPR compatibility also needs to be considered when deploying PGPR in a management strategy.

Few studies have assessed combinations of EcM and PGPR in affecting nutrient acquisition, interactions between symbionts, and plant performance. In $P$. sylvestris, dual colonization with Agrobacterium and Laccaria laccata increased weathering of phlogopite, accompanied by losses of $\mathrm{K}^{+}, \mathrm{Mg}^{2+}$, and $\mathrm{Fe}^{3+}$ (Leyval and Berthelin, 1991). Interestingly, in this study, inoculation with Agrobacterium increased the production of citrate, malate, fumarate, and lactate by roots, whereas roots inoculated with $L$. laccata or both symbionts exhibited a strong suppression of organic acid exudation. Furthermore, Agrobacterium increased root colonization by L. laccata, pointing to the importance of mycorrhizospheric community ecology when addressing plant-soil interactions. Koele et al. (2009), similarly working with P. sylvestris, $L$. bicolor, and Scleroderma citrinum as well as $B$. glathei and Collimonas sp., noted that symbionts differentially altered biotite weathering, especially aiding in $\mathrm{Mg}^{2+}$ access and uptake. Importantly, PGPR strain population persistence was elevated in mycorrhizas versus bulk or rhizosphere soils and was also EcM species dependent, again pointing to important ecological (and related functional) attributes of the tripartite association (Koele et al., 2009). 
In the field, Calvaruso et al. (2007) assessed microbial functional diversity in a Quercus petraea forest by isolating 264 bacterial strains from soils, rhizospheres, and S. citrinum mycorrhizas. Assessment of nutrient mobilizing capacity of these isolate indicated that EcM have a strong influence on the functional ecology of microbial populations, with increased selection for strains that exhibit elevated $\mathrm{Fe}$ and $\mathrm{P}$ solubilization activity from the bulk soil to the fungal sheath (Figure 3).

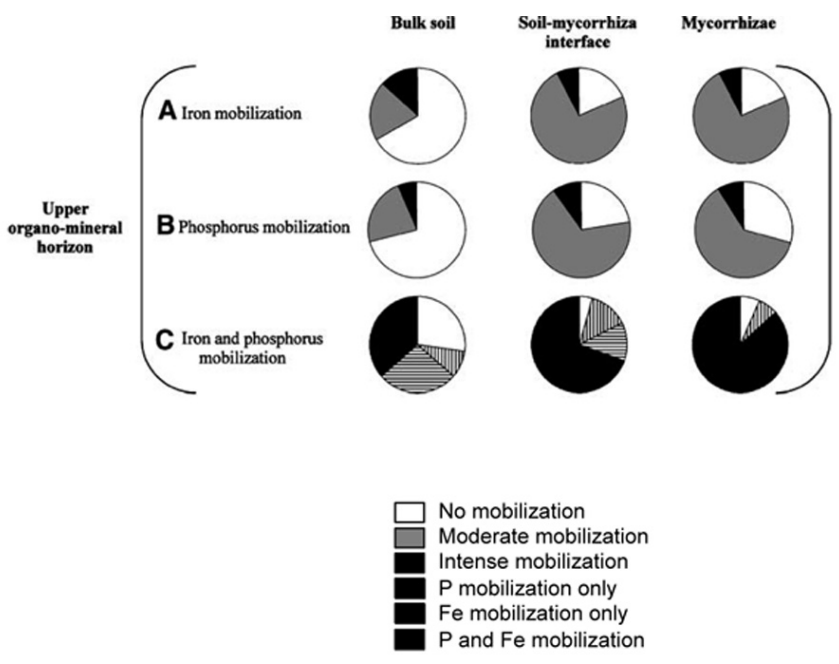

Figure 3. Iron and phosphorus mobilization capacities of microbial communities increase from the bulk soil to the soilmycorrhiza interface to the mycorrhizae of Quercus petraea-Scleroderma citrinum mycorrhizas. Changes in mobilization capacity depicted in pie charts and legend reflect EcM structuring of microbial communities in these microenvironments. Reproduced from Calaruso et al. (2007) with permission.

\section{2. Increasing Organic-P Cycling}

Accessing soil $\mathrm{P}_{\mathrm{o}}$ reserves and transferring $\mathrm{P}$ to the plant host would be a significant benefit of microbial symbionts in forest soils, and several in symbio studies indicate that EcM fungi provide this capacity to forest trees. Mycorrhizas of $N$. oblique formed with P. tinctorius, P. involutus, C. geophilum, and D. antartica exhibited a wide range of APase activities, and $\mathrm{P}$ concentration of host shoots was positively correlated with mycorrhiza APase activity across all symbionts (Alvarez et al., 2012). In addition to correlations of APase activity and plant performance all symbionts (Alvarez et al., 2012). In addition to correlations of APase activity and plant performance in soils, several authors have noted that EcM fungal APase activity is associated with depletion of soil $\mathrm{P}_{\mathrm{o}}$ pools, providing functional support to the reports on APase activity. Native EcM hyphae from roots of $P$. radiata exhibited elevated APase activity that was associated with depletion of $\mathrm{P}_{\mathrm{o}}$ fractions in a forest soil (Liu et al., 2005), and P. involutus hyphae 
extracted $\mathrm{P}$ from leaf litter and transferred $\mathrm{P}$ to host P. sylvestris (Perez-Moreno and Read, 2000). Given the wide range in APase and phytase capacities of EcM species reported, it is clear that selection by the host or edaphic environment of the EcM community has the potential to increase $\mathrm{P}$ acquisition by forest trees (Buée et al., 2007; Courty et al., 2006; Taniguchi et al., 2008).

Little information is available on Po access by PGPR and $\mathrm{P}$ transfer to host plants. Two P. fluorescens and one Rhanella aquatilis strains with high phytase activity provided significant growth enhancement to P. euramericana (368\% increase in height growth) and P. massoniana (69\% increase in height growth) seedlings in a low P forest soil (Li et al., 2013). More work in this area, especially aligning in vitro enzyme activities with performance in symbio, would further elucidate the roles of PGPR in accessing $\mathrm{P}$ in the rhizosphere (see also Becquer et al. 2014).

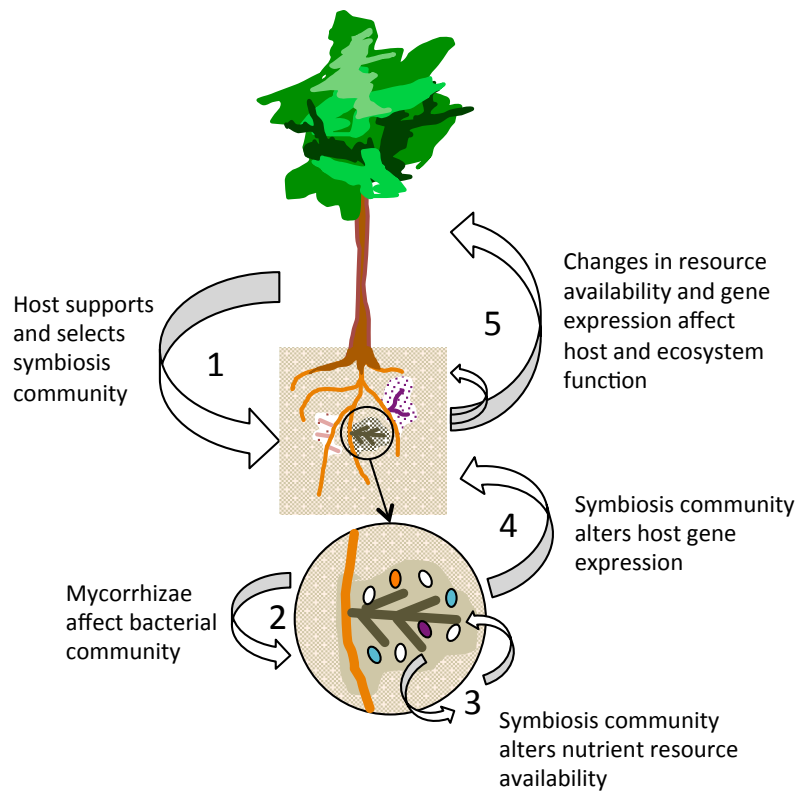

Figure 4. Interactions affecting the acquisition of soil nutrient resources in trees. Selection of the microbial community by host and edaphic factors creates a specialized tree-mycorrhiza-rhizobacterial metaorganism that deploys the genome resources of all symbionts to explore soils, alter nutrient availability, increase acquisition, and alter metabolic pathways to acclimate to nutrient limitation.

\section{Conclusions}

Within soils, biogeochemistry and demand both function to limit Pi availability at the tree root-soil interface. Phosphorus limitation leads to a variety of metabolic stresses and adjustments that serve as aclimation mechanisms to nutrient limitation. The association of symbiotic EcM fungi and PGPR with tree roots greatly influences these stress and acclimation sponses by altering $\mathrm{P}$ availability, acquisition, and metabolism in the mycorrhizosphere. 
While, there is limited process-based understanding of these interactions, it is clear that there are functional ecological processes involved, including host plant selection of EcM communities and subsequent selection of PGPR associates, which creates a metaorganism interacting with the soil environment (Figure 4). Interactions among the partners lead to changes in metagenome expression and deployment of combined physical, physiological, and metabolic systems to explore soils, alter nutrient availability, increase nutrient acquisition, and alter metabolic Interactions among the partners lead to changes in metagenome expression and deployment of combined physical, physiological, and metabolic systems to explore soils, alter nutrient availability, increase nutrient acquisition, and alter metabolic pathways functioning to acclimate to nutrient limitation (Figure 4). The complexity of these relationships and responses influence the functional ecology of the mycorrhizosphere and the larger scale productivity of forested ecosystems.

\section{Acknowledgements}

This contribution originates in part from the "Environment Sensing and Response" Scientific Focus Area (SFA) program at Argonne National Laboratory. This research was supported by the U.S. Department of Energy, Office of Biological and Environmental Research (BER), as part of BER's Genomic Science Program. This research has been funded by the U.S. Department of Energy, Office of Biological and Environmental Research, under contracts FG02-06ER64148 (JRC) and DE-AC0206CH11357 (FRC) and the Department of Agriculture (National Institute for Food and Agriculture contract 2014-67013-21657 (JRC).

\section{References}

Adeleke, R.A., Cloete, T.E., Bertrand, A., Khasa, D.P. 2012. Iron ore weathering potentials of ectomycorrhizal plants. Mycorrhiza. 22(7), 535544.

Adriaensen, K., Vrålstad, T., Noben, J.P., Vangronsveld, J., Colpaert, J.V. 2005. Copperadapted Suillus luteus, a symbiotic solution for pines colonizing $\mathrm{Cu}$ mine spoils. Applied and Environmental Microbiology. 71(11), 7279-7284.

Ali, M.A., Louche, J., Legname, E., Duchemin, M., Plassard, C. 2009. Pinus pinaster seedlings and their fungal symbionts show high plasticity in phosphorus acquisition in acidic soils. Tree Physiolology. 29(12), 1587-1597.

Alvarez, M., Huygens, D., Diaz, L.M., Villanueva, C.A., Heyser, W., Boeckx, P. 2012. The spatial distribution of acid phosphatase activity in ectomycorrhizal tissues depends on soil fertility and morphotype, and relates to host plant phosphorus uptake. Plant Cell Environ. 35(1), 126-135.

Arocena, J., Glowa, K. 2000. Mineral weathering in ectomycorrhizosphere of subalpine fir (Abies lasiocarpa (Hook.) Nutt.) as revealed by soil solution composition. Forest Ecology and Management. 133(1), 61-70.

Augé, R.M. 2004. Arbuscular mycorrhizae and soil/ plant water relations. Canadian Journal of Soil Science. 84(4), 373-381.

Augusto, L., Turpault, M.-P., Ranger, J. 2000. Impact of forest tree species on feldspar weathering rates. Geoderma. 96(3), 215-237.

Babalola, O.O. 2010. Beneficial bacteria of agricultural importance. Biotechnology Letters. 32(11), 1559-1570. 
Baldwin, C., Cumming, J., Timperman, A.T. 2005. Isolation of naturally occurring aluminum ligands using immobilized metal affinity chromatography for analysis by ESI-MS. The Analyst. 130(3), 318-324.

Barriuso, J., Ramos Solano, B., Santamaria, C., Daza, A., Gutierrez Manero, F.J. 2008. Effect of inoculation with putative plant growth-promoting rhizobacteria isolated from Pinus spp. on Pinus pinea growth, mycorrhization and rhizosphere microbial communities. Journal of Applied Microbiology. 105(5), 1298-1309.

Barton, L.L., Northup, D.E. 2011. Microbial Ecology. John Wiley \& Sons, Inc., 440 p.

Bashan, Y. 1990. Short exposure to Azospirillum brasilense $\mathrm{Cd}$ inoculation enhanced proton efflux of intact wheat roots. Canadian Journal of Microbiology. 36(6), 419-425.

Becquer, A., Trap, J., Irshad, U., Ali, M.A., Claude, P. 2014. From soil to plant, the journey of $P$ through trophic relationships and ectomycorrhizal association. Frontiers in Plant Science. 5, 548.

Bent, E., Tuzun, S., Chanway, C.P., Enebak, S. 2001. Alterations in plant growth and in root hormone levels of lodgepole pines inoculated with rhizobacteria. Canadian Journal of Microbiology. 47(9), 793-800.

Berg, G., Smalla, K. 2009. Plant species and soil type cooperatively shape the structure and function of microbial communities in the rhizosphere. FEMS Microbiology Ecology. 68(1), 1-13.

Bertrand, H., Plassard, C., Pinochet, X., Touraine, B., Normand, P., Cleyet-Marel, J. 2000. Stimulation of the ionic transport system in Brassica napus by a plant growth-promoting rhizobacterium (Achromobacter sp.). Canadian Journal of Microbiology. 46(3), 229-236.

Bhattacharyya, P., Jha, D. 2012. Plant growthpromoting rhizobacteria (PGPR): emergence in agriculture. World Journal of Microbiology and Biotechnology. 28(4), 1327-1350.

Blum, J.D., Klaue, A., Nezat, C.A., Driscoll, C.T., Johnson, C.E., Siccama, T.G., Eagar, C., Fahey, T.J., Likens, G.E. 2002. Mycorrhizal weathering of apatite as an important calcium source in basepoor forest ecosystems. Nature. 417(6890), 729731.

Brown, S.D., Utturkar, S.M., Klingeman, D.M., Johnson, C.M., Martin, S.L., Land, M.L., Lu, T.Y., Schadt, C.W., Doktycz, M.J., Pelletier, D.A. 2012. Twenty-one genome sequences from Pseudomonas species and 19 genome sequences from diverse bacteria isolated from the rhizosphere and endosphere of Populus deltoides. Journal of Bacteriology. 194(21), 5991-5993.

Brundrett, M.C. 2009. Mycorrhizal associations and other means of nutrition of vascular plants: understanding the global diversity of host plants by resolving conflicting information and developing reliable means of diagnosis. Plant and Soil. 320(1-2), 37-77.

Buée, M., Courty, P.E., Mignot, D., Garbaye, J. 2007. Soil niche effect on species diversity and catabolic activities in an ectomycorrhizal fungal community. Soil Biology and Biochemistry. 39(8), 1947-1955.

Cairney, J.W. 2000. Evolution of mycorrhiza systems. Naturwissenschaften. 87(11), 467-475.

Cairney, J.W.G. 2012. Extramatrical mycelia of ectomycorrhizal fungi as moderators of carbon dynamics in forest soil. Soil Biology and Biochemistry. 47(0), 198-208.

Calvaruso, C., Turpault, M.P., Frey-Klett, P. 2006. Root-associated bacteria contribute to mineral weathering and to mineral nutrition in trees: A budgeting analysis. Applied and Environmental Microbiology. 72(2), 1258-1266. 
Calvaruso, C., Turpault, M.P., Leclerc, E., FreyKlett, P. 2007. Impact of ectomycorrhizosphere on the functional diversity of soil bacterial and fungal communities from a forest stand in relation to nutrient mobilization processes. Microbial Ecology. 54(3), 567-577.

Carvalhais, L.C., Dennis, P.G., Fan, B., Fedoseyenko, D., Kierul, K., Becker, A., von Wiren, N., Borriss, R. 2013. Linking plant nutritional status to plantmicrobe interactions. PLoS One. 8(7), e68555.

Casarin, V., Plassard, C., Hinsinger, P., Arvieu, J.-C. 2004. Quantification of ectomycorrhizal fungal effects on the bioavailability and mobilization of soil $\mathrm{P}$ in the rhizosphere of Pinus pinaster. New Phytologist. 163(1), 177-185.

Casarin, V., Plassard, C., Souche, G., Arvieu, J.-C. 2003. Quantification of oxalate ions and protons released by ectomycorrhizal fungi in rhizosphere soil. Agronomie. 23(5-6), 461-469.

Cassán, F., Vanderleyden, J., Spaepen, S. 2014. Physiological and agronomical aspects of phytohormone production by model plant-growthpromoting rhizobacteria (PGPR) belonging to the genus Azospirillum. Journal of Plant Growth Regulation. 33(2), 440-459.

Chalot, M., Brun, A. 1998. Physiology of organic nitrogen acquisition by ectomycorrhizal fungi and ectomycorrhizas. FEMS Microbiology Reviews. 22(1), 21-44.

Chapman, S.K., Langley, J.A., Hart, S.C., Koch, G.W. 2006. Plants actively control nitrogen cycling: uncorking the microbial bottleneck. New Phytologist. 169(1), 27-34.

Chen, Y., Rekha, P., Arun, A., Shen, F., Lai, W.-A., Young, C. 2006. Phosphate solubilizing bacteria from subtropical soil and their tricalcium phosphate solubilizing abilities. Applied Soil Ecology. 34(1), 33-41.
Compant, S., van der Heijden, M.G., Sessitsch, A. 2010. Climate change effects on beneficial plantmicroorganism interactions. FEMS Microbiology Ecology. 73(2), 197-214.

Courty, P.E., Buée, M., Diedhiou, A.G., Frey-Klett, P., Le Tacon, F., Rineau, F., Turpault, M.P., Uroz, S., Garbaye, J. 2010. The role of ectomycorrhizal communities in forest ecosystem processes: New perspectives and emerging concepts. Soil Biology and Biochemistry. 42(5), 679-698.

Courty, P.E., Pouysegur, R., Buée, M., Garbaye, J. 2006. Laccase and phosphatase activities of the dominant ectomycorrhizal types in a lowland oak forest. Soil Biology and Biochemistry. 38(6), 1219-1222.

Courty, P.E., Walder, F., Boller, T., Ineichen, K., Wiemken, A., Rousteau, A., Selosse, M.A. 2011. Carbon and nitrogen metabolism in mycorrhizal networks and mycoheterotrophic plants of tropical forests: a stable isotope analysis. Plant Physiologyogy. 156(2), 952-961.

Criquet, S., Ferre, E., Farnet, A. 2004. Annual dynamics of phosphatase activities in an evergreen oak litter: influence of biotic and abiotic factors. Soil Biology and Biochemistry. 36(7), 1111-1118.

Cumming, J.R., Weinstein, L.H. 1990. Aluminummycorrhizal interactions in the physiology of pitch pine seedlings. Plant and Soil. 125(1), 7-18.

den Bakker, H.C., Zuccarello, G.C., Kuyper, T.W., Noordeloos, M.E. 2004. Evolution and host specificity in the ectomycorrhizal genus Leccinum. New Phytologist. 163(1), 201-215.

Desai, S., Naik, D., Cumming, J.R. 2014. The influence of phosphorus availability and Laccaria bicolor symbiosis on phosphate acquisition, antioxidant enzyme activity, and rhizospheric carbon flux in Populus tremuloides. Mycorrhiza. 24(5), 369-382. 
Deveau, A., Gross, H., Morin, E., Karpinets, T., Utturkar, S., Mehnaz, S., Martin, F., Frey-Klett, P., Labbé, J. 2014. Genome sequence of the mycorrhizal helper bacterium Pseudomonas fluorescens BBc6R8. Genome Announcements. 2(1), e01152-01113.

Diedhiou, A.G., Selosse, M.A., Galiana, A., Diabate, M., Dreyfus, B., Ba, A.M., De Faria, S.M., Bena, G. 2010. Multi-host ectomycorrhizal fungi are predominant in a Guinean tropical rainforest and shared between canopy trees and seedlings. Environmental Microbiology. 12(8), 2219-2232.

Elliott, J.C., Smith, J.E., Cromack, K., Chen, H., McKay, D. 2007. Chemistry and ectomycorrhizal communities of coarse wood in young and oldgrowth forests in the Cascade Range of Oregon. Canadian Journal of Forest Research. 37(10), 2041-2051.

Finlay, R., Wallander, H., Smits, M., Holmstrom, S., van Hees, P., Lian, B., Rosling, A. 2009. The role of fungi in biogenic weathering in boreal forest soils. Fungal Biology Reviews. 23(4), 101-106.

Finlay, R.D. 2008. Ecological aspects of mycorrhizal symbiosis: with special emphasis on the functional diversity of interactions involving the extraradical mycelium. Journal of Experimental Botany. 59(5), 1115-1126.

Founoune, H., Duponnois, R., Ba, A., Sall, S., Branget, I., Lorquin, J., Neyra, M., Chotte, J.L. 2002. Mycorrhiza helper bacteria stimulate ectomycorrhizal symbiosis of Acacia holosericea with Pisolithus alba. New Phytologist. 153(1), 81-89.

Franco-Correa, M., Quintana, A., Duque, C., Suarez, C., Rodríguez, M.X., Barea, J.-M. 2010. Evaluation of actinomycete strains for key traits related with plant growth promotion and mycorrhiza helping activities. Applied Soil Ecology. 45(3), 209-217.
Frey-Klett, P., Garbaye, J., Tarkka, M. 2007. The mycorrhiza helper bacteria revisited. New Phytologist. 176(1), 22-36.

Garbaye, J., Bowen, G. 1989. Stimulation of ectomycorrhizal infection of Pinus radiata by some microorganisms associated with the mantle of ectomycorrhizas. New Phytologist. 112(3), 383-388.

Garbaye, J., Bowen, G.D. 1987. Effect of different microflora on the success of ectomycorrhizal inoculation of Pinus radiata. Canadian Journal of Forest Research. 17(8), 941-943.

Gottel, N.R., Castro, H.F., Kerley, M., Yang, Z., Pelletier, D.A., Podar, M., Karpinets, T., Uberbacher, E., Tuskan, G.A., Vilgalys, R., Doktycz, M.J., Schadt, C.W. 2011. Distinct microbial communities within the endosphere and rhizosphere of Populus deltoides roots across contrasting soil types. Applied Environmental Microbiology. 77(17), 5934-5944.

Graham, J.H., Miller, R.M. 2005. Mycorrhizas: Gene to function. Plant and Soil. 274(1-2), 79-100.

Gyaneshwar, P., Kumar, G.N., Parekh, L., Poole, P. 2002. Role of soil microorganisms in improving $P$ nutrition of plants, In: J. J. Adu-Gyamfi (ed), Food Security in Nutrient-Stressed Environments: Exploiting Plants' Genetic Capabilities. Springer, pp: 133-143.

Hartmann, A., Schmid, M., van Tuinen, D., Berg, G. 2009. Plant-driven selection of microbes. Plant and Soil. 321(1-2), 235-257.

Helm, D., Allen, E., Trappe, J. 1996. Mycorrhizal chronosequence near Exit Glacier, Alaska. Canadian Journal of Botany. 74(9), 1496-1506.

Hou, E., Chen, C., McGroddy, M.E., Wen, D. 2012. Nutrient limitation on ecosystem productivity and processes of mature and old-growth subtropical forests in China. PLoS One. 7(12). 
Hrynkiewicz, K., Ciesielski, A., Haug, I., Baum, C. 2010. Ectomycorrhiza formation and willow growth promotion as affected by associated bacteria: role of microbial metabolites and use of C sources. Biology and Fertility of Soils. 46(2), 139-150.

Idriss, E.E., Makarewicz, O., Farouk, A., Rosner, K., Greiner, R., Bochow, H., Richter, T., Borriss, R. 2002. Extracellular phytase activity of Bacillus amyloliquefaciens FZB45 contributes to its plantgrowth-promoting effect. Microbiology. 148(7), 2097-2109.

Izumi, H., Finlay, R.D. 2011. Ectomycorrhizal roots select distinctive bacterial and ascomycete communities in Swedish subarctic forests. Environmental Microbiology. 13(3), 819-830.

Johansson, E.M., Fransson, P.M.A., Finlay, R.D., Van Hees, P.A.W. 2008. Quantitative analysis of root and ectomycorrhizal exudates as a response to $\mathrm{Pb}$, Cd and As stress. Plant and Soil. 313(1-2), 39-54.

Johansson, E.M., Fransson, P.M.A., Finlay, R.D., van Hees, P.A.W. 2009. Quantitative analysis of soluble exudates produced by ectomycorrhizal roots as a response to ambient and elevated $\mathrm{CO}_{2}$. Soil Biology and Biochemistry. 41(6), 1111-1116.

Keller, S., Schneider, K., Süssmuth, R.D. 2006. Structure elucidation of auxofuran, a metabolite involved in stimulating growth of fly agaric, produced by the mycorrhiza helper bacterium Streptomyces AcH 505. Journal of Antibiotics. 59(12), 801-803.

Khan, A.A., Jilani, G., Akhtar, M.S., Naqvi, S.S., Rasheed, M. 2009. Phosphorus solubilizing bacteria: occurrence, mechanisms and their role in crop production. Journal of Agricultural and Biological Sciences. 1(1), 48-58.

Koele, N., Turpault, M.-P., Hildebrand, E.E., Uroz, S., Frey-Klett, P. 2009. Interactions between mycorrhizal fungi and mycorrhizosphere bacteria during mineral weathering: Budget analysis and bacterial quantification. Soil Biology and Biochemistry. 41(9), 1935-1942.

Kretzer, A.M., King, Z.R., Bai, S. 2009. Bacterial communities associated with tuberculate ectomycorrhizae of Rhizopogon spp. Mycorrhiza. 19(4), 277-282.

Labbe, J.L., Weston, D.J., Dunkirk, N., Pelletier, D.A., Tuskan, G.A. 2014. Newly identified helper bacteria stimulate ectomycorrhizal formation in Populus. Frontiers in Plant Science. 5,579 .

Leong, J. 1986. Siderophores: their biochemistry and possible role in the biocontrol of plant pathogens. Annual Review of Phytopathology. 24(1), 187-209.

Leyval, C., Berthelin, J. 1991. Weathering of a mica by roots and rhizospheric microorganisms of pine. Soil Science Society of America Journal. 55(4), 1009-1016.

Li, G.-E., Wu, X.-Q., Ye, J.-R., Hou, L., Zhou, A.D., Zhao, L. 2013. Isolation and identification of phytate-degrading rhizobacteria with activity of improving growth of poplar and Masson pine. World Journal of Microbiology and Biotechnology. 29(11), 2181-2193.

Liu F., Xing, S., Ma, H., Du, Z., Ma, B. 2013. Plant growth-promoting rhizobacteria affect the growth and nutrient uptake, of Fraxinus americana container seedlings. Applied Microbiology and Biotechnology. 97(10), 4617-4625.

Liu, Q., Loganathan, P., Hedley, M. 2005. Influence of ectomycorrhizal hyphae on phosphate fractions and dissolution of phosphate rock in rhizosphere soils of Pinus radiata. Journal of Plant Nutrition. 28(9), 1525-1540. 
Loper, J.E., Henkels, M.D. 1999. Utilization of heterologous siderophores enhances levels of iron available to Pseudomonas putida in the rhizosphere. Applied Environmental Microbiology. 65(12), 5357-5363.

Lopez, B.R., Tinoco-Ojanguren, C., Bacilio, M., Mendoza, A., Bashan, Y. 2012. Endophytic bacteria of the rock-dwelling cactus Mammillaria fraileana affect plant growth and mobilization of elements from rocks. Environmental and Experimental Botany. 81, 26-36.

Loth-Pereda, V., Orsini, E., Courty, P.E., Lota, F., Kohler, A., Diss, L., Blaudez, D., Chalot, M., Nehls, U., Bucher, M., Martin, F. 2011. Structure and expression profile of the phosphate Pht1 transporter gene family in mycorrhizal Populus trichocarpa. Plant Physiology. 156(4), 21412154.

Louche, J., Ali, M.A., Cloutier-Hurteau, B., Sauvage, F.-X., Quiquampoix, H., Plassard, C. 2010. Efficiency of acid phosphatases secreted from the ectomycorrhizal fungus Hebeloma cylindrosporum to hydrolyse organic phosphorus in podzols. FEMS Microbiology Ecology. 73(2), 323-335.

Machado, C.T.d.T., Furlani, Â.M.C. 2004. Root phosphatase activity, plant growth and phosphorus accumulation of maize genotypes. Scientia Agricola. 61(2), 216-223.

Mantelin, S., Touraine, B. 2004. Plant growthpromoting bacteria and nitrate availability: impacts on root development and nitrate uptake. Journal of Experimental Botany. 55(394), 27-34.

Marschner, H., Marschner, P. 2012. Marschner's Mineral Nutrition of Higher Plants. Academic Press, London, UK, 672 p.

Massicotte, H., Molina, R., Tackaberry, L., Smith, J., Amaranthus, M. 1999. Diversity and host specificity of ectomycorrhizal fungi retrieved from three adjacent forest sites by five host species. Canadian Journal of Botany. 77(8), 10531076.

Massicotte, H.B., Molina, R., Luoma, D.L., Smith, J.E. 1994. Biology of the ectomycorrhizal genus, Rhizopogon. New Phytologist. 126(4), 677-690.

Mogge, B., Loferer, C., Agerer, R., Hutzler, P., Hartmann, A. 2000. Bacterial community structure and colonization patterns of Fagus sylvatica L. ectomycorrhizospheres as determined by fluorescence in situ hybridization and confocal laser scanning microscopy. Mycorrhiza. 9(5), 271-278.

Molina, R., Massicotte, H., Trappe, J.M. 1992. Specificity phenomena in mycorrhizal symbioses: community-ecological consequences and practical implications,. In: M. F. Allen (ed), Mycorrhizal Functioning: An Integrative PlantFungal Process. Chapman and Hall, New York, NY, pp: 357-423.

Nygren, C., Rosling, A. 2009. Localisation of phosphomonoesterase activity in ectomycorrhizal fungi grown on different phosphorus sources. Mycorrhiza. 19(3), 197-204.

Obase, K., Cha, J.Y., Lee, J.K., Lee, S.Y., Lee, J.H., Chun, K.W. 2009. Ectomycorrhizal fungal communities associated with Pinus thunbergii in the eastern coastal pine forests of Korea. Mycorrhiza. 20(1), 39-49.

Perez-Moreno, J., Read, D.J. 2000. Mobilization and transfer of nutrients from litter to tree seedlings via the vegetative mycelium of ectomycorrhizal plants. New Phytologist. 145(2), 301-309.

Persello-Cartieaux, F., Nussaume, L., Robaglia, C. 2003. Tales from the underground: molecular plant-rhizobacteria interactions. Plant Cell Environ. 26(2), 189-199.

Phillips, R.P., Fahey, T.J. 2006. Tree species and mycorrhizal associations influence the magnitude of rhizosphere effects. Ecology. 87(5), 1302-1313. 
Plassard, C., Dell, B. 2010. Phosphorus nutrition of mycorrhizal trees. Tree Physiolology. 30(9), 1129-1139.

Plaxton, W.C., Tran, H.T. 2011. Metabolic adaptations of phosphate-starved plants. Plant Physiology. 156(3), 1006-1015.

Puente, M.E., Bashan, Y., Li, C.Y., Lebsky, V.K. 2004. Microbial populations and activities in the rhizoplane of rock-weathering desert plants. I. Root colonization and weathering of igneous rocks. Plant Biology. 6(5), 629-642.

Riedlinger, J., Schrey, S.D., Tarkka, M.T., Hampp, R., Kapur, M., Fiedler, H.P. 2006. Auxofuran, a novel metabolite that stimulates the growth of fly agaric, is produced by the mycorrhiza helper bacterium Streptomyces strain AcH 505. Applied Environmental Microbiology. 72(5), 3550-3557.

Rodríguez, H., Fraga, R. 1999. Phosphate solubilizing bacteria and their role in plant growth promotion. Biotechnology Advances. 17(4), 319-339.

Rodriguez, H., Fraga, R., Gonzalez, T., Bashan, Y. 2006. Genetics of phosphate solubilization and its potential applications for improving plant growthpromoting bacteria. Plant and Soil. 287(1-2), 1521.

Rogers, A., McDonald, K., Muehlbauer, M.F., Hoffman, A., Koenig, K., Newman, L., Taghavi, S., Lelie, D. 2012. Inoculation of hybrid poplar with the endophytic bacterium Enterobacter sp. 638 increases biomass but does not impact leaf level physiology. GCB Bioenergy. 4(3), 364-370.

Rosling, A., Landeweert, R., Lindahl, B.D., Larsson, K.H., Kuyper, T.W., Taylor, A.F.S., Finlay, R.D. 2003. Vertical distribution of ectomycorrhizal fungal taxa in a podzol soil profile. New Phytologist. 159(3), 775-783.

Saccone, L., Gazzè, S.A., Duran, A.L., Leake, J.R., Banwart, S.A., Ragnarsdóttir, K.V., Smits,
M.M., McMaster, T.J. 2012. High resolution characterization of ectomycorrhizal fungalmineral interactions in axenic microcosm experiments. Biogeochemistry. 111(1-3), 411425.

Schrey, S.D., Schellhammer, M., Ecke, M., Hampp, R., Tarkka, M.T. 2005. Mycorrhiza helper bacterium Streptomyces AcH 505 induces differential gene expression in the ectomycorrhizal fungus Amanita muscaria. New Phytologist. 168(1), 205-216.

Seguel, A., Cumming, J.R., Klugh-Stewart, K., Cornejo, P., Borie, F. 2013. The role of arbuscular mycorrhizas in decreasing aluminium phytotoxicity in acidic soils: a review. Mycorrhiza. 23(3), 167-183.

Smith, S.E., Read, D.J. 2008. Mycorrhizal Symbiosis. Elsevier Academic Press, Amsterdam, The Netherlands, 787 p.

St. Clair, S.B., Sharpe, W.E., Lynch, J.P. 2008. Key interactions between nutrient limitation and climatic factors in temperate forests: a synthesis of the sugar maple literature. Canadian Journal of Forest Research. 38(3), 401-414.

Taniguchi, T., Kataoka, R., Futai, K. 2008. Plant growth and nutrition in pine (Pinus thunbergii) seedlings and dehydrogenase and phosphatase activity of ectomycorrhizal root tips inoculated with seven individual ectomycorrhizal fungal species at high and low nitrogen conditions. Soil Biology and Biochemistry. 40(5), 1235-1243.

Taylor, A.F.S., Hills, A.E., Simonini, G., Both, E.E., Eberhardt, U. 2006. Detection of species within the Xerocomus subtomentosus complex in Europe using rDNA-ITS sequences. Mycological Research. 110(3), 276-287. 
Tedersoo, L., May, T.W., Smith, M.E. 2010 Ectomycorrhizal lifestyle in fungi: global diversity, distribution, and evolution of phylogenetic lineages. Mycorrhiza. 20(4), 217263.

Turan, M., Gulluce, M., von Wirén, N., Sahin, F. 2012. Yield promotion and phosphorus solubilization by plant growth-promoting rhizobacteria in extensive wheat production in Turkey. Journal of Plant Nutrition and Soil Science. 175(6), 818-826.

Uroz, S., Calvaruso, C., Turpault, M., Sarniguet, A., De Boer, W., Leveau, J., Frey-Klett, P. 2009. Efficient mineral weathering is a distinctive functional trait of the bacterial genus Collimonas. Soil Biology and Biochemistry. 41(10), 21782186.

van Breemen, N., Lundström, U.S., Jongmans, A.G. 2000. Do plants drive podzolization via rockeating mycorrhizal fungi? Geoderma. 94(2), 163171.

Van Hees, P.A.W., Rosling, A., Essén, S., Godbold, D.L., Jones, D.L., Finlay, R.D. 2006. Oxalate and ferricrocin exudation by the extramatrical mycelium of an ectomycorrhizal fungus in symbiosis with Pinus sylvestris. New Phytologist. 169(2), 367-378.

van Hees, P.A.W., Rosling, A., Lundström, U.S., Finlay, R.D. 2006. The biogeochemical impact of ectomycorrhizal conifers on major soil elements (Al, Fe, K and Si). Geoderma. 136(1-2), 364-377.

Van Schöll, L., Hoffland, E., Van Breemen, N. 2006 Organic anion exudation by ectomycorrhizal fungi and Pinus sylvestris in response to nutrient deficiencies. New Phytologist. 170(1), 153-163.

Van Tichelen, K.K., Colpaert, J.V. 2000. Kinetics of phosphate absorption by mycorrhizal and nonmycorrhizal Scots pine seedlings. Physiologia Plantarum. 110(1), 96-103.

Wallander, H. 2000. Uptake of P from apatite by Pinus sylvestris seedlings colonised by different ectomycorrhizal fungi. Plant and Soil. 218(1-2), 249-256.

Wardle, D.A., Bardgett, R.D., Klironomos, J.N., Setälä, H., Van Der Putten, W.H., Wall, D.H. 2004. Ecological linkages between aboveground and belowground biota. Science. 304(5677), 1629-1633.

Yang, J., Kloepper, J.W., Ryu, C.-M. 2009. Rhizosphere bacteria help plants tolerate abiotic stress. Trends in Plant Science. 14(1), 1-4.

Zhang, H., Sun, Y., Xie, X., Kim, M.S., Dowd, S.E., Paré, P.W. 2009. A soil bacterium regulates plant acquisition of iron via deficiency-inducible mechanisms. The Plant Journal. 58(4), 568-577. 